\title{
Grundtvig-Konference i Indien
}

\author{
Af K. E. Bugge
}

At Grundtvigs skoletanker har vundet udbredelse i Den tredje Verden, har man længe vidst. Ikke desto mindre vil det nok forbavse de fleste, at en international Grundtvig-konference i januar 1999 gennemførtes i Indien. Konferencen fandt sted på Jadavpur University i Calcutta. I det følgende skal først berettes om konferencens kontekst, hvorefter arrangørerne præsenteres. Efter nogle ord om programmet og deltagerne, skal et par centrale temaer fremdrages og kommenteres. Afsluttende opridses nogle af konferencens perspektiver.

\section{Kontekst}

Calcutta vil være de fleste bekendt som hjemstedet for Mother Theresas selvopofrende arbejde blandt slumbeboerne. Det vil imidlertid være urigtigt kun at associere byens navn med nød og elendighed. Calcutta var den største by i det britiske imperium næst efter London og hovedstad i britisk Indien helt frem til 1912. Byens brede gader, flotte muséer og rummelige parker bærer vidnesbyrd om denne fortid.

I den regionale sammenhæng var Calcutta hovedstad for provinsen Bengalen, et område hvis økonomiske velstand i høj grad byggede på jute-industrien. I indisk sammenhæng har netop Calcutta haft uoverskuelig stor betydning, dels som center for et blomstrende kulturliv, dels som politisk knudepunkt. I begge henseender har Calcutta gennem flere århundreder været en inspiration for resten af Indien.

Gennem århundreder har Calcutta været kendt som lærdomscenter. Her har man ikke alene dyrket studiet af Sanskrit og af de klassiske religiøse tekster. Siden omkr. år 1800 har byens intellektuelle også været dybt engageret i sociale og politiske reformer. Denne blanding af kultur, lærdom og reformiver har her sat sig spor i en tidlig indsats for at skabe forbedrede uddannelsesmuligheder for de underpriviligerede. En foregangsmand på dette område var den her i Danmark næsten ukendte Ishwarchandra Vidyasagar (1820-1891). På Jadavpur University, der oprettedes i 1956, fortsættes denne tradition. 
Asoke Bhattacharya, der er professor ved Jadavpur University, har både $\mathrm{i}$ efteråret 1997 og i 1998 været på studiebesøg i Danmark.I Grundtvig-Studier 1998 er det første af disse besøg, hvor han ledsagedes af sin kollega Dr. Tandra Mitra, kort omtalt; endvidere har han i samme årgang offentliggjort en artikel under titlen »People's Education in India."

Professor Bhattacharya er leder af universitetets center for voksenuddannelse: "Adult, Continuing Education and Extension Centre" (ACEE). Centerets aktiviteter er opdelt i en akademisk og en ikke-akademisk sektor. I den førstnævnte afdeling forestår man fortscttelseskurser (»Continuing Education«) for interesserede på flere forskellige niveauer, over 40 kurser i alt. Disse kurser sigter mod opnåelse af bestemte kvalifikationer, der kan forbedre vedkommendes indtægts-og karrieremuligheder. Muligvis vil man kunne sammenligne denne undervisning med vort »Åbent Universitet «. Endvidere driver centeret forskning på voksenuddannelsesområdet. Det er netop i forbindelse med centerets forskning, at man har søgt og opnået kontakt med udenlandske kolleger. Endelig er centeret aktivt mht. udvikling af undervisningsmaterialer, bl.a. produktion af videoer.

Den ikke-akademiske virksomhed er benævnt »Extension and Field Outreach «. Extension-arbejdet kan formentlig sammenlignes med vort Folkeuniversitet. Der er her tale om undervisning, der er tilgængelig for alle uden hensyntagen til akademiske forudsætninger, og der sigtes ikke mod nogen bestemt eksamen. - Outreach-arbejdet udgør centerets praktiske feltarbejde i et bestemt, afgrænset lokalområde. Her gennemføres læse-og skrivekurser (»literacy programmes «) samt opfølgende kurser for dem, der har opnået denne færdighed. Endvidere arrangeres et mindre antal praktiske, erhvervsforberedende kurser. Blandt de nyeste initiativer inden for feltarbejdet kan nævnes undervisning af Calcuttas gadebørn og af handicappede. Det er således i denne ikkeakademiske virksomhed, at den for byens lærdomscentre karakteristiske forening af akademiske studier og socialt engagement gør sig gældende. Det er også på dette punkt, at man på ACEE-centeret føler sig i dyb overensstemmelse med intentioner i den danske folkehøjskole. 
Ud over de nævnte aktiviteter anser man det også for vigtigt at oprette og vedligeholde gode forbindelser både til medierne, dvs. til presse, radio og TV, samt til private organisationer, de såkaldte NGOs, dvs. Non-Government Organisations. Endelig skal nævnes centerets videnskabelige publikationer, der bl.a. omfatter professor Bhattacharyas interessante bog »Empowering the Neoliterates", trykt i Calcutta i 1994. I undertitlen, der lyder $»$ Relevance of Danish Folk High School and Co-operative Movements for Adult Education in India«, knyttes en direkte forbindelse til Danmark.

Hele denne mangesidige virksomhed varetages af tre videnskabelige medarbejdere, en teknisk assistent samt et kontorpersonale på to sekretærer og to kontorbude. Det er ikke mange især i betragtning af, at den ene af de tre videnskabelige stillinger var ubesat. Ikke desto mindre var det fra dette miljø, at indbydelsen til konferencen udgik. Det var imponerende, hvad disse ret fă personer magtede at få stillet på benene.

\section{Program og deltagere}

Konferencen strakte sig over to dage: Fredag d. 15/1 - Lørdag d. 16/1-1999. Den officielle åbnings-ceremoni (»Inauguration«) indledtes med en smuk recitation af Tagores digt om den sande frihed, "Where the mind is without fear". Derpå fulgte en række korte indlæg, $9 \mathrm{i}$ alt. Talerne repræsenterede dels universitetet,dels fremtrædende politikere, bl.a. delstatens finansminister, dels de organisationer og institutioner, som ACEE samarbejder med, heriblandt andre universiteter i Calcutta. Center for Grundtvig-Studier, Aarhus Universitet, var repræsenteret af professor Jens Holger Schjørring.

En rastløs vestlig konference-deltager kunne muligvis undre sig over, at en så udførlig indledningsceremoni var påkrævet. Den indiske praksis tjener imidlertid flere nyttige formål. Dels bliver en række af deltagerne præsenteret for forsamlingen, dels får arrangøren (ACEE) på den måde mulighed for at kvittere for opbakning bag konferencen. Først som sidst tjener ceremonien dog til, at der falder en velsignet ro over sindene.

Om eftermiddagen tog man så fat på rækken af plenum-foredrag med efterfølgende drøftelse. To danske $\mathrm{g}$ to indiske talere havde ordet. Lørdag formiddag bragte fem foredrag på hver en halv times tid. Ordstyrereren var her Tanvir 
Mokammel fra Bangladesh. Et halvt års tid forinden havde han på sit modersmål Bengali udgivet en bog om Grundtvig. Oversat til engelsk lyder titlen "Grundtvig and People's Education«. Lørdag eftermiddag afsluttedes konferencen med fem foredrag og afrundende opsamling og tak til de medvirkende.

Det var lidt vanskeligt at fastslå antallet af deltagere. Fra værtslandet var der 16 talere, hvoraf nogle kun deltog i åbningsceremonien. Fra Danmark var kommet 9, fra Bangladesh 2 samt en enkelt deltager fra hvert af de øvrige lande, USA, England og Sverige. Derudover deltog som tilhørere ca. 20 kolleger fra andre institutter på universitetet samt ca. 30 studerende, der vandrede ud og ind.

Uden for programmet, men i snæver tilknytning til konferencen, var for de udenlandske deltagere arrangeret en to-dages udflugt til Tagores Shantiniketan. Historiske tråde forbinder denne berømte institution med Danmark og folkehøjskolen. I 1926 aflagde Tagore besøg på Den Internationale Højskole, Helsingør. Et foto fra denne begivenhed ses bl.a. i Max Lawsons jubilæumsskrift til skolen (1996). Shantiniketan, der nu har status som universitet, er center for pædagogisk og landbrugs-økonomisk udviklingsarbejde.

\section{Temaer}

Konferencens første hovedtema var Grundtvig, hvis tanker og virkningshistorie blev udførligt behandlet af en række udenlandske foredragsholdere (A.M. Allchin, K.E. Bugge, Kim Arne Pedersen, J.H.Schjørring, Lilian Zøllner) og i de indiske bidrag især af Asoke Bhattacharya. I disse bidrag blev Grundtvig præsenteret for en kreds af tilhørere med meget varierende forudsætninger, og man gjorde rede for nyere strømninger inden for Grundtvig-forskningen. Nogle søgte desuden at trække forbindelseslinier til konferencens hovedtema: Undervisning og udvikling. Også flere af de indiske foredragsholdere kom ind på Grundtvig, der, som det blev sagt, opfattedes »mainly as an educational thinker«. Relevansen af Grundtvigs tanker for udviklingslandene blev tydeligt fremhævet, idet dog understregedes, at det ikke gjaldt om at overføre, men om at tilpasse hans ideer. »Not transfer but adaptation«. Professor Dilip Kumar Sinha fra Visva-Bharati University i Calcutta tilføjede, at Grundtvig og Tagore havde visioner. $\mathrm{Nu}$ gjaldt det om analyse og praksis. 
Konferencens andet store tema var "Education and Development", undervisning og udvikling. Bidragene til belysning af dette emne kunne opdeles i to grupper. Talerne i den ene gruppe leverede en række interessante oplysninger om den aktuelle situation i Indien mht. undervisning og skolegang for folkets brede masser.

Et centralt anliggende er her bestræbelserne for at fremme befolkningens "literacy«, dvs. læse- og skrivefærdighed. Ifølge professor Pabitra Sarkar var læsefærdighedsprocenten i 1901 5,35\%; i 1951 var den 16,67\%, og ifølge den nyeste opgørelse fra 1991 er den 52,21\%. Et enkelt distrikt i delstaten Kerala opnåede i 1989 »full literacy«, og siden er andre distrikter fulgt efter. I den efterfølgende diskussion drøftedes bl.a. hvad der helt præcist skal forstås ved "full literacy«.

I den anden gruppe af bidrag rettedes søgelyset især mod forholdet mellem undervisning og udvikling. Professor Amiya Kumar Dev fra Vidyasagar University i Calcutta fastslog som sin opfattelse, at der ikke kan være tale om udvikling, før hele befolkningen har gennemgået grundskolen (»universal primary education«). De efterfølgende foredrag gjorde opmærksom på en række problemer i dette projekt. Den førnævnte professor Sarkar påpegede, at det kunne være svært at få »de oplyste« tilbage til landsbyerne, en opfattelse der deltes af Dr. Patricia Sharpe fra USA. Finansminister Ashim Dasgupta gjorde opmærksom på, at undervisning i hvert fald ikke i sig selv er tilstrækkeligt. For at skabe udvikling vil den enkelte landsbybo desuden have brug for jord, kapital og et godt helbred!

På konferencens anden dag fortsattes diskussionen af professor Holger Bernt Hansen fra Københavns Universitet. HBH gjorde indledningsvis gældende, at man lige så godt kunne sige, at udvikling var forudsætning for undervisning, som omvendt. Under alle omstændigheder måtte forholdet mellem disse to størrelser ikke ensidigt anskues som et forløb, der udfolder sig i et før og et efter. Der er snarere tale om en nødvendig samtidighed. Hvad dette angår henvistes til den indiske nobelpristager, økonomen $\mathrm{R}$. Sen, der har udtalt, at »education should be geared to development $\ll$.

Derpå anholdt HBH begrebet /adult education« og gjorde rede for dets mangetydighed. Endvidere blev det med eksempler illustreret, hvorledes man i Den tredje Verden prioriterer forholdet mellem almen og erhvervsforberedende undervisning anderledes end i de vestlige lande. Denne forskel i prio- 
ritering bringer en skævhed ind $i$ ulandenes forventninger til den danske folkehøjskoles idé. Dertil kommer problemerne med at sammenligne enhedskulturen i det 19. århundredes Danmark på den ene side og den brogede mangfoldighed af sprog og kulturer i de nye afrikanske og asiatiske stater på den anden. Begreber som modersmål og nation giver her helt andre associationer.

Afsluttende rejstes spørgsmålet, om Den tredje Verden faktisk har brug for Grundtvig. Efter HBHs opfattelse er svaret ja, dersom man bruger Grundtvig på rette måde, bl.a. til at inspirere befolkningen til at tage et politisk ansvar.Det siger sig selv, at dette oplæg, der gjorde op med mange gængse forestillinger, gav anledning til en omfattende og livlig diskussion.

\section{Perspektiver}

Af fremadrettede perspektiver kan nævnes, at Asoke Bhattacharya har planer om at oprette et Grundtvig-Institut som nyt forsknings- og uddannelsescenter ved Jadavpur University. I løbet af sommeren er der udarbejdet et dokument, der dels præsenterer idéen, dels indgår som bilag til en ansøgning om økonomisk støtte.

Dersom man får held med dette initiativ, vil et nyt Grundtvig-Institut kunne slutte sig til dem, der i løbet af de senere år er oprettet dels i Nigeria, dels ved Göteborg Universitet. Under alle omstændigheder er der grund til at ønske professor Asoke Bhattacharya tillykke med alt det, han til dato har udrettet, ikke mindst med gennemførelsen af den her omtalte, i alle henseender vellykkede konference.

Men også selve ACEE-centeret er der grund til at lykønske. I september modtog det UNESCOs hæderspris for fremragende indsats på voksenundervisningens område. Prisen blev overrakt i New Delhi d. 8. september 1999-på Grundtvigs fødselsdag, naturligvis! 